\section{The Effects of Google Word Coach Game and Vocabulary Mastery on Students' Speaking Skill}

\author{
1 Suryadi \\ 2 Winda Widyaningrum \\ 3 Fajar Erlangga
}

1 STKIP Situs Banten, Indonesia

23 Universitas Indraprasta PGRI Jakarta, Indonesia

\section{Abstract}

The research aims to examine the effects of Google Word Coach game and vocabulary mastery on students' speaking skills. This quasi-experimental study uses a $2 \times 2$ nonequivalent control group design with a factorial design carried out in four parallel classes, namely class XI IPS 1, XI IPS 2, XI IPS 3 and XI IPS 4 MA Negeri 1 Serang. Learning outcome data are obtained through pretest and posttest activities. The samples are 80 students randomly taken by adjusting to the condition and aim of the research. The results show a significant difference between the posttest of the experimental group and that of the control group. $F_{0}$ value is 5.225 and Sig. is $0.025<0.05$. Thus, it shows that the null hypothesis is rejected, and the research hypothesis is accepted. It also means that there is a difference between the interaction effect of Google Word Coach game and that of vocabulary mastery on students' speaking skills.

\section{Keywords}

Google Word Coach vocabulary mastery speaking skill

\section{Ethical Lingua}

Vol. 7, No. 1, 2020

ISSN 2355-3448 (Print) ISSN 2540-9190 (Online)

Corresponding Email

Suryadi

suryadiyadi426@yahoo.com

Article's History

Submitted 30 Dec 2019

Revised 8 April 2020

Revised 9 April 2020

Accepted 9 April 2020

DOI

10.30605/25409190.146

Copyright $\odot 2020$

The Author(s)

This article is licensed under CC BY-NC-SA 4.0 License

\section{(cc) EY-NC-SA}




\section{The Effects of Google Word Coach Game and Vocabulary Mastery on Students' Speaking Skill}

In Indonesia, English has been being taught as a compulsory subject in all education levels starting from elementary school level, high school levels until university level. In Indonesia, English generally taught by applying a conventional or traditional method that focuses on the learning and teaching grammar and structure aspects. Students are usually asked to make and analyze well-structured sentences and memorize and pronounce vocabularies. In higher level of education, they are asked to take an English paper test about grammar and reading comprehension. The listening and speaking aspects are rarely practiced. The English competence (knowing the grammar and vocabulary) that has much priority and spend so much time is not well balanced with speaking practice to improve oral production as a communicative performance (Mustafa, 2000). It means that Indonesian students receive considerably massive exposure to grammar but little exposure to a communicative situation. As a result, after graduating from high schools, they cannot speak English well. The nine years of learning English does not finally upgrade Indonesian students' skill to express their thoughts in English or engage in an English conversation. Learning to speak a language is a difficult task for foreign language students because it requires the ability to use the language. Students have to choose the correct vocabulary to describe the items, to rephrase or emphasize words to clarify the description if the listener or receiver cannot understand. The students in XI IPS grade at MA Negeri 1 Serang cannot speak fluently because they are lack of vocabularies. The students speak only a few sentences because they cannot find the appropriate vocabularies to be used to express their ideas because they lack vocabulary.

Vocabulary is one of language elements considered necessary for language mastery. A linguistic study shows that vocabulary is more important than the structure since a thought is mainly delivered by a word. After mastering the vocabulary, students are expected to be able to communicate fluently. Vocabulary has been viewed as a core component of language proficiency. As Nation (2002:267) states, vocabulary growth is such an important part of language acquisition that it deserves to be planned for, deliberately controlled, and monitored. Vocabulary mastery plays an important role in learning the language. Annisa (2010:6) defines mastery as comprehensive knowledge. According to Annisa (2010:6), mastery is a skill to use knowledge.

Based on the conditions above, the teachers are demanded to choose the most appropriate teaching technique according to the students' preferences. By using the most appropriate technique, it is hoped that the students will learn in the best way so that the successful teaching and learning target can be achieved. Teachers also should be able to recognize and understand how their students learn. Understanding the way students learn can be helpful for the teachers to find the appropriate technique to be used in the class so that more effective teaching techniques can be performed. In the speaking class, there are some teaching techniques that can be applied by the teachers. English teaching involves four language skills; they are listening, reading, writing, and speaking. Specifically, the four language skills are grouped into two divisions, namely, productive skills such as writing and speaking, and receptive skills such as reading and listening. Then, the aspects that support the four language skills above, such as grammar, vocabulary, spelling, and pronunciation are also taught in English teaching and learning process. 
In this case, the teachers and students need to be involved, especially in the teaching and learning process, to make the process run effectively and efficiently in the class. The learning materials provided must be able to make students active during the teaching and learning process. For example, discussing and making simple conversations using sentences often used in daily conversations. According to Agil (2012), a visual medium is simpler and easier to bring anywhere. A medium is one of the important things to support the teaching of speaking and is very determinative in the learning achievement. The previous research becomes one of the author's references in conducting research so that the author can enrich the theories used in his research.

The objectives of this research are to know; 1) the interaction effects of Google Word Coach game and vocabulary mastery on students' speaking skills. 2) the effect of Google Word Coach game on students' speaking skills. 3) the effect of vocabulary mastery on students' speaking skills. Meanwhile, the hypothesis of this research are: 1) There are no interaction effects of Google Word Coach game and vocabulary mastery on students' speaking skills, and there are interaction effects of Google Word Coach game and vocabulary mastery on students' speaking skill. 2) There is no effect of google coach game on students' speaking skills, and there is an effect of Google Word Coach game on students' speaking skills. 3) There is no effect of vocabulary mastery on students' speaking skills, and there is an effect of vocabulary mastery on students' speaking skills.

\section{Method}

This research used a quantitative approach by which hypotheses are tested to show the causal relationships between variables (Degeng, 2000: 13). The research design is a factorial design, which is a variation between-group designs consisting of two or more treatment variables to test the independent variables and the simultaneous effect on treatment variables on an outcome (Creswell, 2009: 159). In other words, factorial design was defined as a research structure that includes independent variables, mode variables, and dependent variables where the size of the analysis of variance was equal to the number of independent variables and moderator variables (Tuckman, 1999: 306). Other experts claim that this study can also be referred to as a factorial design in a non-equivalent control group design, specifically $2 \times 2$ factorial design (Degeng, 2000: 15).

The research subjects are all XI IPS MA Negeri 1 Serang students in the 2018/2019 academic year. The number of students are four classes. Each class consists of 40 people, with a total of 160 students from 4 classes. However, from the four classes randomly chosen as the sample, only two classes are used, namely class XI IPS 1 as an experimental class and class XI IPS 2 as a control class Both the control class and the experimental class consist of 40 students or the total number of active students until the final stage of the activity is as many as 80 students as research subject.

After giving the initial test (pre-test), the researcher conducts homogeneity tests using Levene's test before treatment. Homogeneity of the test is designed to test the version of the normal distribution of the population, the homogeneity of the test is carried out employing the Levene's test. Research data collected from a homogenous population are considered adequate if significance is $\alpha=0.05$. If $F_{\text {observed }}<F_{\text {table }}$. It can be concluded that data is homogeneous or otherwise. 
Table 1. Factorial Design $2 \times 2$

\begin{tabular}{llll}
\hline & \multicolumn{2}{c}{ Teaching Technique } & $\sum$ Rows \\
\cline { 2 - 3 } Vocabulary Mastery & $\begin{array}{l}\text { Google Word Coach } \\
\text { Game } \\
\text { (A1) }\end{array}$ & $\begin{array}{l}\text { Conventional teaching } \\
\text { method } \\
\text { (A2) }\end{array}$ & $\sum$ A1 \\
\hline High (B1) & A1B1 & A2B2 & $\sum$ A2 \\
Low (B2) & A2B2 & A2B2 & $\sum$ Total \\
\hline Columns & $\Sigma$ B1 & $\Sigma$ B2 & \\
\hline
\end{tabular}

Note:

A : Teaching Method

A1 : Google Word Coach game

A2 : Conventional Teaching Method

B : Vocabulary Mastery

B1 : High

B2 : Low

Y : Students' Speaking Skill

A1B1 : The group of students with high vocabulary mastery taught using Google word coach game.

A1B2 : The group of students with low vocabulary mastery taught using a conventional teaching method.

A2B1 : The group of students with high vocabulary mastery taught using Google word coach game.

A2B2 : The group of students with low vocabulary mastery taught using a conventional teaching method.

The treatment is carried out to prove whether the application of Google Word Coach Game can facilitate students' mastering English vocabulary and can help students to develop their ability to speak English. The treatment is carried out eight times with the same allocation of time for each meeting for the control class and the experiment class, which is $3 \times 50$ minutes or 150 minutes and starts every Monday at 09.50-12.20 for the experimental class and for the control class is held every Tuesday at 09:50-12.20. The learning materials are set in the Lesson Plan (RPP). The instruments of the research are vocabulary and speaking tests. Vocabulary and speaking tests are conducted in the first meeting and the last meeting. In the vocabulary tests, the students are asked to answer the 40 questions. Speaking test is aimed at figuring out the student's ability to communicate in spoken English orally before and after having treatment of learning process.

There are six procedures performed in this research. First procedure is determining the population and selecting the samples. The second is selecting and arranging the materials to be taught as a pretest. The researcher chooses the materials from the students' handbook based on the syllabus. Then, the third procedure is administering the pretest. Pretest is needed to know the achievement of the students' vocabulary and speaking skill. After that, the fourth procedure is conducting the treatments. In Google Word Coach game, students are asked to play a Google Word Coach game given by the teacher then asked to speak their vocabularies in front of the class and communicate with the other groups to answer the questions. In Google Word Coach game class, the students are asked to speak about vocabularies given by the teacher and ask the other group to answer the questions. The fifth procedure is administering the posttest. The last procedure is analyzing the data. The 
researcher scores the students final work from the pretest and posttest. After that the researcher analyzes the scores by comparing the scores of those two kinds of test.

The data are collected by giving two kinds of test to the students. In the pretest, the researcher asks the students to answer the vocabulary and speaking tests. In treatments, the researcher teaches how to play Google Word Coach game and how to speak English. In the posttest, the students are asked to do the vocabulary and speaking tests similar to the pretest. The research data are then analyzed to test the difference in average score with two independent variables, then the hypothesis of research is tested using the two-way analysis of variance (ANOVA).

\section{Results}

In order to find out the interaction effects of Google Word Coach game and vocabulary mastery on students' speaking skill, the researcher administers pretest and posttest. After obtaining the data, the researcher analyzes them through SPSS by comparing the posttest of Google Word Coach game.

As the result, there is a significant difference in vocabulary of students taught through Google Word Coach game. The technique that improves the students' vocabulary effectively is Google Word Coach game. It can be seen from the difference in the average of score of the test between the class XI IPS 1 and class XI IPS 2 after treatment and before treatment. In class XI IPS 1, the student's mean score before treatment is 68.55 and the mean score after treatment is 86.70 . In class XI IPS 2, the student's mean score before treatment is 65.40 and the mean score after treatment is 73.55 . It suggests that teaching vocabulary using Google Word Coach game is better than applying conventional method.

Table 2. Description of Statistic according to Design of the Research

\begin{tabular}{llll}
\hline & \multicolumn{2}{c}{ Teaching $(\mathrm{A})$} & \\
\cline { 2 - 3 } \begin{tabular}{l} 
Vocabulary mastery \\
\cline { 2 - 3 }
\end{tabular} & Google coach game $\left(\mathrm{A}_{1}\right)$ & $\begin{array}{l}\text { Conventional teaching } \\
\text { method }\left(\mathrm{A}_{2}\right)\end{array}$ & Total \\
\hline Pictures & $\mathrm{n}=20$ & $\mathrm{n}=20$ & $\mathrm{n}=40$ \\
& $\hat{X}=86.70$ & $\hat{X}=73.55$ & $\hat{X}=77.62$ \\
& $\mathrm{~s}=6.250$ & $\mathrm{~s}=8.351$ & $\mathrm{~s}=13.896$ \\
Dictionary & $\mathrm{n}=20$ & $\mathrm{n}=20$ & $\mathrm{n}=40$ \\
& $\hat{X}=68.55$ & $\hat{X}=65.40$ & $\hat{X}=69.48$ \\
& $\mathrm{~s}=13.563$ & $\mathrm{~s}=9.489$ & $\mathrm{~s}=9.740$ \\
& $\mathrm{n}=40$ & $\mathrm{n}=40$ & $\mathrm{n}=80$ \\
& $\hat{X}=77.63$ & $\hat{X}=69.47$ & $\hat{X}=73.55$ \\
& $\mathrm{~s}=19.82$ & $\mathrm{~s}=17.84$ & $\mathrm{~s}=23.64$ \\
\hline
\end{tabular}


Table 3. Levene's Test

Levene's Test of Equality of Error Variances ${ }^{\mathrm{a}}$

Dependent Variable: Speaking Skill

\begin{tabular}{llll}
\hline$F$ & $d f 1$ & $d f 2$ & Sig. \\
1,148 & 3 & 76 &, 335 \\
\hline
\end{tabular}

Tests the null hypothesis that the error variance of the dependent variable is equal across groups.

a. Design: Intercept $+A+B+A * B$

Table 4. The test of ANOVA 2 ways

\begin{tabular}{llllll}
$\begin{array}{l}\text { Tests of Between-Subjects Effects } \\
\text { Dependent Variable: Speaking Skill }\end{array}$ & & & & \\
\hline Source & $\begin{array}{l}\text { Type III Sum of } \\
\text { Squares }\end{array}$ & df & Mean Square & F & Sig. \\
\hline $\begin{array}{l}\text { Corrected } \\
\text { Model }\end{array}$ & $5286,900^{\circ}$ & 3 & 1762,300 & 18,416 &, 000 \\
Intercept & 432768,200 & 1 & 432768,200 & 4522,320 &, 000 \\
A & 1328,450 & 1 & 1328,450 & 13,882 &, 000 \\
B & 3458,450 & 1 & 3458,450 & 36,140 &, 000 \\
A * & 500,000 & 1 & 500,000 & 5,225 &, 025 \\
Error & 7272,900 & 76 & 95,696 & & \\
\hline Total & 445328,000 & 80 & & & \\
Corrected Total & 12559,800 & 79 & & & \\
\hline
\end{tabular}

a. R Squared $=, 421$ (Adjusted R Squared $=, 398$ ) 
Table 5. Multiple Comparisons

\begin{tabular}{|c|c|c|c|c|c|c|}
\hline \multicolumn{7}{|c|}{ Multiple Comparisons } \\
\hline \multicolumn{7}{|c|}{ Dependent Variable: Speaking Skill } \\
\hline \multicolumn{7}{|c|}{ Tukey HSD } \\
\hline \multirow[t]{2}{*}{$\begin{array}{l}\text { (I) Post } \\
\text { Hoc }\end{array}$} & \multirow[t]{2}{*}{$\begin{array}{l}\text { (J) Post } \\
\text { Hoc }\end{array}$} & \multirow{2}{*}{$\begin{array}{l}\text { Mean } \\
\text { Difference } \\
(I-J)\end{array}$} & \multirow[t]{2}{*}{$\begin{array}{l}\text { Std. } \\
\text { Error }\end{array}$} & \multirow[t]{2}{*}{ Sig. } & \multicolumn{2}{|c|}{$\begin{array}{l}95 \% \text { Confidence } \\
\text { Interval }\end{array}$} \\
\hline & & & & & $\begin{array}{l}\text { Lower } \\
\text { Bound }\end{array}$ & $\begin{array}{l}\text { Upper } \\
\text { Bound }\end{array}$ \\
\hline \multirow{3}{*}{ A1B1 } & A1B2 & $18,15^{*}$ & 3,093 & ,000 & 10,02 & 26,28 \\
\hline & A2B1 & $13,15^{*}$ & 3,093 & ,000 & 5,02 & 21,28 \\
\hline & A2B2 & $21,30^{*}$ & 3,093 & ,000 & 13,17 & 29,43 \\
\hline \multirow{3}{*}{ A1B2 } & A1B1 & $-18,15^{*}$ & 3,093 & ,000 & $-26,28$ & $-10,02$ \\
\hline & A2B1 & $-5,00$ & 3,093 & ,376 & $-13,13$ & 3,13 \\
\hline & A2B2 & 3,15 & 3,093 & ,739 & $-4,98$ & 11,28 \\
\hline \multirow{3}{*}{ A2B1 } & A1B1 & $-13,15^{*}$ & 3,093 & 000 & $-21,28$ & $-5,02$ \\
\hline & A1B2 & 5,00 & 3,093 & ,376 & $-3,13$ & 13,13 \\
\hline & A2B2 & $8,15^{*}$ & 3,093 & ,049 & ,02 & 16,28 \\
\hline \multirow{3}{*}{ A2B2 } & A1B1 & $-21,30^{*}$ & 3,093 & ,000 & $-29,43$ & $-13,17$ \\
\hline & A1B2 & $-3,15$ & 3,093 & 739 & $-11,28$ & 4,98 \\
\hline & A2B1 & $-8,15^{\star}$ & 3,093 & ,049 & $-16,28$ &,- 02 \\
\hline
\end{tabular}

Based on observed means.

The error term is Mean Square(Error) $=95,696$.

*. The mean difference is significant at the 0,05 level.

\section{Discussion}

Furthermore, the answer to the first research question about the interaction effects of Google Word Coach game and vocabulary mastery on students' speaking skill can be seen from $\mathrm{F}_{\mathrm{o}}$ value of 5.225 and Sig of $0.025<0.05$. So, it means that the null hypothesis is rejected and the research hypothesis is accepted. It shows that there is a difference in interaction effects of Google Word Coach game and vocabulary mastery on student's speaking skills.

For the second research question, the researcher tries to find out the effect of Google Word Coach game on students' speaking skills. The researcher analyzes the data by comparing the students' scores of Google Word Coach game. The result of the use of Google Word Coach game on students' speaking skill shows a significant effect of Google Word Coach game on students' speaking skill, meaning that google coach game helps them to study English better. 
It is proven by $F_{0}$ of 13.882 and Sig of $0.000<0.005$. Those techniques improve students' vocabulary achievement to the level of satisfaction of $50.4 \%$. Based on the result of the effect of Google Word Coach game on students' speaking skill, it can be concluded that Google Word Coach game is an appropriate technique to be used in order to improve students' vocabulary achievement. So, it means that the null hypothesis is rejected and the research hypothesis is accepted. It shows that there is a difference in Google Word Coach game technique.

For the third research question, the researcher tries to find out the effect of vocabulary mastery on students' speaking skill. There is a significant effect of vocabulary mastery on students' speaking skill. It is proven by Fo of 36.140 and Sig of $0.000<0.05$. The result also shows that vocabulary mastery gives a contribution for $45.6 \%$ on the increase in students' speaking skill. So, it means that the null hypothesis is rejected and the research hypothesis is accepted. It also means that there is an effect of vocabulary mastery on student's speaking skill.

The Google word coach game is effectively used in teaching vocabulary to improve students' vocabulary for speaking skill. It is proven by;1) the students' response are very good, and their scores from first until third treatment are improved. 2). the students can easily remember the vocabularies that have been taught. It is proven by the students' score. In their final score, most of the students get 9 score in doing the task. 3). Students' responses to Google Word Coach game used by the teacher in teaching vocabulary are: All of the students are happy and interested in the use of this game. Most students point out that it is very useful and make remembering vocabulary easier for them. The result of this research also shows that the technique gives positive effects in improving student's vocabulary mastery.

The students do not do the game well enough. However, there are still some students who seem motivated while doing the game or the activity. The result of this research also shows that using those techniques makes most of the students motivated when doing the activity and doing the test. From the pre-activity to the post-activity, the students are more active and enthusiastic in learning vocabulary. Based on that fact, the researcher can conclude that the higher student's vocabulary mastery is, the better of the student's speaking skill will be. Learning vocabulary aims at enabling students to understand the concepts of unfamiliar words, gain a greater number of words, and use words successfully for communicative purposes. Grabe (2009:279) stated that raising the students' awareness of the new words that they encounter in texts represents an important learning goal. Finally, according to the explanation above, it can be concluded that there are difference effects of Google Word Coach game and vocabulary mastery on students' speaking skill. This technique can improve students' vocabulary and speaking skill.

\section{Conclusion}

Based on the research on the effects of the Google Word Coach Game and vocabulary mastery on students' speaking skill, it can be concluded as follows. (1) there is a significant difference between vocabulary mastery of students learning with the Google Word Coach game and of those learning with a conventional way. Students who are taught using Google Word Coach game can master the vocabularies better than students who are taught using the conventional way. (2) students who have high vocabulary mastery differ significantly in the ability to speak English with students who have low vocabulary mastery, both taught by using Google Word Coach Games and conventional way. (3) There are significant interaction effects of Google 
Word Coach game and vocabulary mastery on students' speaking skill. Thus, it can be proven that using Google word coach games has better results in mastering vocabulary and has a significant effect on students' speaking skill.

There are some suggestions referred to the conclusions above. First suggestion for the English teachers, in order to improve the students' vocabulary and to make the process of teaching learning process more fun and can be caught well, the researcher suggests that all English teachers should be able to find and choose an appropriate method or technique in teaching English to students in senior high schools. Google word coach game is a good technique to teach vocabulary. The game should be implemented for all students. It aims to avoid the student's boredom and to attract the students' motivation to learn more about English, especially vocabularies. That is why the form of Google Word Coach game is very easy to understand. Google Word Coach Game helps students to improve the mastery of English vocabulary so that they are able to speak English properly and correctly.

The second suggestion is for further research. This research is conducted at the Senior High School level. Therefore, further researches can be conducted to find out the effects of Google Word Coach game and mastery vocabulary on students' speaking skill in different education levels. In this research, multiple choices are employed as the media to measure the improvement of students' vocabulary achievement. Further researches can apply those techniques with another kind of vocabulary test, such as an essay test.

\section{Acknowledgment}

The researcher would like to express gratitude to the institution, STKIP Situs Banten, the Head of English Education Department, the Research Institute and Community Service (Lembaga Penelitian dan Pengabdian Masyarakat) of STKIP Situs Banten.

\section{References}

Agil, K. (2012). Teaching Speaking Through Visual Media. Retrieved from http://artcorners.blogspt.com, accessed at June 12.

Annisa, I. (2010). Improving Students' Vocabulary Mastery using Experimental Learning On the Sixth Grade of SDN Banaran 01 Sukoharjo, p.3. Accessed from interact 23 November 2013.

Creswell, J. W. (2009). Research Design: Qualitative, Quantitative, and Mixed Methods Approaches. Newbury Park: Sage publications.

Degeng, I. N. S. (2000). Metodologi Penelitian. Malang: Pascasarjana Universitas Negeri Malang.

Grabe, W. 2009. Reading in a Second Language: Moving from Theory to Practice. Cambridge: Cambridge University Press.

Mustafa, B. (2000). Communicative language teaching in Indonesia: Issues of theoretical Assumption and Challenges in the Classroom Practice. TEFLIN Journal, 11(1). p.3749.

Nation, I. S. P. (2002). Learning Vocabulary in Another Language. p. 267. Cambridge: Cambridge University Press.

Tuckman, B. W. (1999). Conducting Educational Research (4th ed.). New York: Harcout Brace College Publisher. 